\title{
THE BODY OF THE MOTHER IN CONTEMPORARY BLACK WOMEN NARRATIVES: (RE)WRITING IMMANENCE TOWARDS TRANSCENDENCE
}

\author{
Cristina Stevens* \\ Universidade de Brasília \\ Brasília, DF, BR
}

\begin{abstract}
Articulating class, gender and race issues, we analyze black motherhood in novels by contemporary black women writers, the harsh reality of this experience under slavery, colonization and its consequences in contemporary society. They expose the bodily aspects of labor, in deep contrast with the patriarchal, idealized images of Western motherhood; in doing so, however, they reject its characterization as a purely immanent process which defines and entraps women's body in utterly distorted, essentialist terms.
\end{abstract}

Key words: black motherhood; contemporary literature; feminist studies.

We know that the word mother (latin: mater matter) associates her with her bodily, immanent nature; however, there is already a considerable theoretical production about the body of the mother as discourse, and motherhood as cultural construct. Today, it is impossible to explain human behavior in biological terms only: at the same time, it is also widely accepted that biology can be understood as a moral science as well. When researching about the body of the mother, we continually have to face this problematic opposition nature/culture, which has caused so much misconception, exploitation, and control of women's lives.

Our lives are demarcated by two great, and silent, mysterious experiences: birth and death, about which innumerable and totalizing explanations have been produced, most of them from a patriarchal perspective. Labor pain as a punishment for Eve's sin as established in Genesis, as well as the taboos disguised as science and religion, trying to explain women's bodily processes as menstruation, gestation, birthing, clearly indicate the attempts to control these processes that take place in the body of women.

For centuries, women were reduced to their bodies, raw material from which men can create life in all its complex, cultural and symbolic manifestations. The dichotomy nature/culture has had devastating consequences for women, since it has enslaved us as immanent bodies only, of which transcendence is the male counterpart. It has ancient origins, as can be seen Aristotle's notions about the differences between men and women:

$[\ldots]$ the female is, as it were, a mutilated male, and the catamenia are semen, only not pure; for there is only one thing that they have not in them, the principle of the soul. [...] the female always provides the material, the male that which fashions it, for this is the power that we say each possesses, and this is what is meant by calling them male and female. Thus while it is necessary for the female to provide a body and a material mass, it is not necessary for the male, because it is not within the work of art or the

Doutora em Estudos Linguísticos e Literários em Inglês pela Universidade de São Paulo (1987). Pós doutorado: Centre for Interdisciplinary Gender Studies Leeds University/UK (2003). Pesquisadora Colaboradora da Universidade de Brasília (UnB). Coordenadora do Grupo de Pesquisa VOZES FEMININAS (www. vozesfemininas.com.br). Coordenou o GT/ANPOLL “A Mulher na Literatura” (biênio 2010/12). E-mail: cristinastevens@gmail.com. 
embryo that the tools or the maker must exist. While the body is from the female, it is the soul that is from the male, for the soul is the reality of a particular body. (Aristotle, apud Agonito 46-47 italics mine)

Judeo and Christian dogmas have reinforced men's supremacy in the creation of life. From women's sexual freedom in primeval societies, to the sacred status of chastity and frailty, myriad discursive constructions try to explain and control women's bodies, transforming them into abject objects (Kristeva, 1982). ${ }^{1}$

The body of the mother was transformed into a scapegoat for the fears of mortality, the temptations of the flesh; women were associated with everything that is vile, inferior, corruptible, material. According to the historian Mary del Priore, this association is reinforced by St. Agustin, who places the birthing act near faeces and urine; woman's body was described as "a deposit of filth" and the uterus "a territory of utility and abjection" (Del Priore 313). Women's breasts were "work tools"; any association between breasts and the beauty and sexuality of women would bring terrible punishment as: "milk fever, inflammation, abscess, malign tumors" (Del Priore 249). This tradition has had long-lasting effects in the distortion of this vital experience for the whole of humanity; in the beginning, there was the womb, and it becomes the word.

Influenced by the "fertilizing" (not seminal) contribution of Simone de Beauvoir, who defined motherhood as "the trap of nature" (495), feminist studies for some time placed body issues (the theme of motherhood included) in potential conflict with women's interests. This attitude indicated that we saw biology, not patriarchal attitudes and discourses around it, as our enemies. However, after the 1970s, several studies began to appear among feminist theorists, aiming at historicizing important aspects related to women's body, making increasingly obvious the ideological uses of biology.

In relation to the experience of motherhood, ${ }^{2}$ the main objective of such studies was to increase women's awareness about the dominant, idealized, image of the domestic mother, as a sexless, selfless woman whose only power was moral persuasion and the superintending of her children's spiritual, intellectual, social, and physiological development. They also expose and analyze the underlying reasons for the cruel distortions of bourgeois, patriarchal notions about what is experienced only in the body of women; instead, they emphasize the positive potential of this condition. Rich, complex and varied materials have been produced in areas such as sociology, history, religion, anthropology, psychoanalysis. According to Psychoanalysis, on the other hand, the body of the mother is the locus of our forever lost union with the mother, our first libidinal object, source of the mystery and fears of the preoedipian, pre-symbolic stages of our lives. The works of Adrienne Rich, Nancy Chodorow, Dorothy Dinnerstein, Julia Kristeva, Helene Cixous, have produced relevant contributions in this aspect.

For feminist psychoanalysts such as Luce Irigaray, our phallologocentric society is founded upon matrophobia. This constitutes a rich source for imagining the "hermeneutics of the repressed", the unconscious phase of our primal fusion with the body of the mother, that has to be abandoned in the process of creating conscious mechanisms that form the basis of our patriarchal society. She questions the silences of psychoanalysis:

The relation with the mother is a mad desire, because it is a "dark continent" par excellence. She remains in the shadow of our culture. [...] Could the father substitute the uterus with language? But his law refuses any representation of that body, that first love. It is sacrificed to form the empire of representation, which privileges the masculine and the human race. (Irigaray 10-14)

This concept of the body of the mother as a locus of semiotic-the primal phallus that men steal, making her absent/present, the body before representation-has, for Kristeva, strong subversive power, since it is from this "stage zero" that the imaginary, palimpsest of our subjective formations, develops itself. The maternal body is rearticulated in language as well as in art, as Marianne Hirsch reminds us, quoting Barthes: "the writer always plays with the body of the mother" (Hirsch 52). 
Literature plays an important role in the creation of new ideas, practices and values. In relation to the experience of motherhood, women writers have been producing remarkable novels which not only problematize limited, patriarchal notions about this vital experience for human life; they also create new images about the body of the mother, almost nonexistent in canonical literature. ${ }^{3}$

As we know, more recent contributions in the area of gender studies have successfully changed these essentialist notions of masculine-feminine. I would emphasize the work of Gayle Rubin and Jane Flax; both feminist scholars analyze the distinction between sex and gender, a vital contribution to women's struggle. ${ }^{4}$ Donna Haraway's (1991) ground-breaking contribution to the influence of culture and discourse on our "cyborguian" bodies was fertilizing as well.

Judith Butler's notion (1990) of the role of performativity in the formation of the subject and the matter of our bodies has had ontological implications. In Bodies that Matter (1993), she emphasizes the relation between performativity and the materialization of our sexed bodies. In "Contingent Foundations", Butler further problematizes the ontological materiality of body and sex-for her, sites of power relations. While reinforcing the illusion of universality and fundamentalism, she argues in favour of a "contingent" notion of the subject, without which, there is no political struggle:

To deconstruct the concept of matter or that of bodies is not to negate or refuse either term. To deconstruct these terns means, rather, to continue to use them, to repeat them, to repeat them subversively, and to displace them from the contexts in which they have been deployed as instruments of oppressive power. [...] To problematize the matter of bodies entails in the first instance a loss of epistemological certainty, but this loss of certainty does not necessarily entail political nihilism as its result. If a deconstruction of the materiality of bodies suspends and problematizes the traditional ontological referent of the term, it does not freeze, banish, render useless, or deplete of meaning the usage of the term; on the contrary, it provides the conditions to mobilize the signifier in the service of an alternative production. ${ }^{5}$
In History of Sexuality Foucault (I, 1990) also sees the connection between discursive practices and the materiality of the bodies, the site of productive power forces. He does not deny the relevance of the physical body; instead, he explains how power politics relate directly to the body/bodies, and how it affects decisively its functions and processes-physiological and psychological, its pains and pleasures. Feminist materialism has also brought body issues back to the academic and political debate. In her text "Posthumanist Performativity: Toward an Understanding of How Matter Comes to Matter", Karen Barad (2003) proposes a "relational ontology" as the basis for her concept of "agential realism". She writes:

Far from the body having to be effaced, what is needed is to make it visible through an analysis in which the biological and the historical are not consecutive to one another [...] but are bound together in an increasingly complex fashion in accordance with the development of the modern technologies of power that take life as their objective. Hence, I do not envision a "history of mentalities" that would take account of bodies only through the manner in which they have been perceived and given meaning and value; but a "history of bodies" and the manner in which what is most material and most vital in them has been invested. (81)

\section{"The metaphysics of presence"-the body of the mother}

Despite varied, complex practices, beliefs and manifestations, motherhood is a universal, transcultural experience, since the vast majority of women become mothers, and we all have had mothers once-men and women, no matter how complex the meaning of those two words. This relevant experience has been enriched by new practices and discourses. A vast material is increasingly being produced, not only trying to reinforce traditional ideologies but also radically contradicting them. Apart from religious, scientific, legal, fictional material, we come across personal reports that explore the experiences of divergent forms of maternity, and of specific mothers or groups of mothers, such as 
poor, working-class mothers, immigrant mothers, black mothers, single mothers, "fallen" mothers, lesbian mothers, surrogate mothers, abusive mothers, homosexual couples who "mother" adopted children, and so many others.

In canonical literature, as well as in Western culture in general, the image of black women has been mainly that of an object for sexual pleasure. Other images constructed them as instruments for invisible reproductive and slave labor. If we focus our attention on fictional material and we move away from canonical literature, we identify novels written by black women writers that brings us a different scenario. In contrast with the traditional, patriarchal, eurocentric image of the mother, contemporary black women writing is analyzed as a public celebration of the maternal presence, and her love for her children is seen as an act of resistance in developing a loved sense of the self, whose central aim is empowerment of their children in a racist society. In this context, home is a place for nurturance as resistance, a place to restore dignity denied in the unloving world outside the family, which naturalizes blacks as inferior.

In her research about matrifocal family structures, the anthropologist Nancy Tanner shows how Western cultural biases, and what she sees as ethnocentrism in the social sciences, have profoundly affected kinship theory in general. She compared the culturally defined role of the mother in Indonesia and Africa with motherhood among black Americans. Tanner shows a structural solidarity which places women in a strong position as mothers, a role that is culturally elaborate and valued more than that of wife: the cultural image of the mother as simultaneously strong and nurturing, a source of wisdom. Community mothering-an inheritance from African communal lifestyle with its collective responsibility for childcare provides, according to Tanner, new models of social transformation in the black American family system, which, for her, has a matrifocal emphasis, with extended, flexible kin network system (152).

The contemporary American writer Toni Morrison reinforces the positive image of motherhood. In an interview with the researcher Andrea O'Reilly for her book Toni Morrison and motherhood-a politics of the heart, Morrison talks about her own experience of being a mother: "I have never felt oppressed or disempowered by it [...] for me, it was the most liberating thing that ever happened" (O'Reilly x). Her novels are peopled with remarkably strong mothers; however, she also exposes the harsh reality of black motherhood in racist Western society in its crude, physical manifestations. In Morrison's Sula (1973), the fiercely independent and much hated Sula Peace is raised by her grandmother Eva, because her mother was seen as a promiscuous, care-free woman who burns to death early in the novel, without ever playing the role of "the good mother"; it is suggested that Eva put her own leg under a train in order to get insurance money to raise her three adopted children. In The Bluest Eye (1970), the young Pecola gets pregnant by her own father-ironically called Cholly Breedlove, giving birth to a dead child, after which she goes insane.

These contemporary fictional constructions deal with the body of the mother in quite different images from those we see in canonical literature. Some of these dramatic images of the mother would not be uncommon poor, destitute communities, but it is almost completely ignored by writers in general.

Sometimes, these mothers come to the extreme action of committing infanticide, like Eva (Sula) and Sethe (Beloved), the reasons for which are completely understood by the reader. In Beloved (1987), Sethe gets pregnant from a rape that is witnessed by her black lover, who takes refuge in madness to cope with this most cruel form of emasculation and disempowerment a man can think of. The pregnant Sethe gives birth to a child, while running away to escape slavery. The author describes the physicality of the birthing act in detail, which, based on my readings of contemporary Literature, is absent:

As soon as Sethe got close to the river, her own waters broke loose to join it. The break, followed by the redundant announcement of pain, arched her back. [...] Panting under four summer stars, she threw her legs over the sides, because here come the head, as Amy informed her, as if she did not know it-as though the rip was a breakup of walnut logs in 
a brace, or of lightning's jagged tear through a leather sky. [...] "Push!" screamed Amy. "Pull", whispered Sethe. And the strong hands went to work a fourth time, none too soon, for river water, seeping through any hole it chose, was spreading over Sethe's hips. She reached one arm and grabbed the rope while Amy fairly clawed at the head. When a foot rose from the riverbed and kicked the bottom of the boat and Sethe's behind, she knew it was done and permitted herself a short faint. (Morrison 83-4)

When she is finally caught, she decides that her child will not become a slave as she had been:

[...] what it took to drag the teeth out of that saw under the little chin; to feel the baby blood plump like oil in her hands; to hold her face so that her head would stay on; to squeeze her so that she could absorb, still, the death spasms that shot through that adored body, plump and sweet with life-Beloved must leave. Leave before [...] anybody white could take your whole self for anything that came to mind. Not just work, kill, or maim you, but dirty you. (Morrison 251)

Once only, and in a radical way, this bigger-thanlife character is in control of her child's body and life, as she never had been of hers. As the mixed-race female narrator of Barbara Chase-Riboud's novel ${ }^{6}$ painfully exclaims: "I had learned so young that my body was not my own" (234).

The loosely autobiographical novel The Autobiography of my Mother (1997), by the CaribbeanAmerican writer Jamaica Kincaid, features conflict with both a strong maternal figure and colonial and neocolonial influences. The main character's mother is absent from the whole novel, ${ }^{7}$ which is narrated from the daughter's point of view. Xuela (part Caribbean, and part Scottish and African) begins her story by telling us she never knew her own mother, herself an orphan also; this painful realization recurs throughout the novel. Xuela longs to (re)constructing this presence in absence in a narrative which borders the Unheimlich ${ }^{8}$ :

When my mother was born (so I was told), her mother wrapped her in some clean pieces of cloth and placed her outside a place where some nuns from France lived; they brought her up, baptized her a Christian, and demanded that she be a quiet, shy, long-suffering, unquestioning, modest, wishing-to-die-soon person. She became such a person. The attachment, spiritual and physical, that a mother is said to have for her child, that confusion of who is who, flesh and flesh, that inseparableness which is said to exist between mother and child? All this was absent between my mother and her own mother. How to explain this abandonment, what child can understand it? That attachment, physical and spiritual, that confusion of who is who, flesh and flesh, which was absent between my mother and her mother was also absent between my mother and myself, for she died at the moment I was born, and though I can sensibly say to myself such a thing cannot be helped, for who can help dying, again how can any child understand such a thing, so profound an abandonment? I have refused to bear any children. (199)

These feelings are intercalated with events in Xuela's life, her solitary childhood without love or protection, her colonial schooling, her emotionless but intense sexual encounters which she enjoys without any feeling of guilt. Discovering that she is pregnant, she chooses not to be a mother herself and opts for a bloody, painful self-inflicted abortion, which leaves her barren for the rest of her life. The scene is described with frank and horrific detail that is quite an unfamiliar territory in literature, which has traditionally silenced about women's bodily processes and their positive/ negative manifestations.

I did not smell of the dead, because for something to be dead, life would have had to come first. I had only made the life that was just beginning in me, not dead, just not to be at all. There was a pain between my legs; it started inside my lower abdomen and my lower back and came out through my legs, this pain. I was wet between my legs; I could smell the wetness; it was blood, fresh and old. The fresh blood smelled like a newly dug-up mineral that had not yet been refined and turned into something worldly, something to which a value could be assigned. The old blood gave off a sweet rotten stink, and this I loved and would breathe in 
deeply when it came to dominate the other smells in the room; perhaps I only loved it because it was mine. (91)

When she detachedly faces the end of her rather nihilistic life, the personal narrative of these immanent sensations all point towards transcendence, towards the "thing greater than I am" (228).

The Nigerian-English writer Buchi Emecheta was sixteen when she married Sylvester Onwordi, and joined him in London, where he was studying. She gave birth to five children in six years. It was an unhappy and sometimes violent marriage and, at the age of twenty-two, Emecheta left her husband, after which, she had to support her five children alone, while still writing and studying for her BSc degree in Sociology at the University of London, where she also got her $\mathrm{PhD}$ in 1990.

Although she comments in an interview for the BBC that for her, children and creativity are strongly linked, ${ }^{9}$ Emecheta is very critical of motherhood as vital in defining womanhood, as can be seen in The Joys of Motherhood. Published in 1979, her novel explores the burden of colonialism, racial prejudice and, especially the absence of the "joys of motherhood" for a mother of nine children. Emecheta unravels the ordeals of Nnu Ego, the worn-out West African "Everywoman", and ironic icon of maternal self-sacrifice. The novel begins with a dramatic account of her physical and emotional pain at the loss of her first child:

She felt and at the same time, did not feel the pain. This was true of the pain in her young and unsupported breasts, now filling fast with milk since the birth of her baby boy four weeks before. Her baby ... her baby! Nnu Ego's arms involuntarily went to hold her aching breasts, more for assurance of her motherhood than to ease their weight. She felt the milk trickling out, wetting her buba blouse; and the other choking pain got heavier, nearing her throat, as if determined to squeeze the very life out of her there and then. But, unlike the milk, this pain could not come out, though it urged her one, and she was running, running away from it. (2)

The chapters' titles- "The Mother," "The Mother's Mother," "The Mother's Early Life," "A Mother's
Investment", "Mother of Clever Children"-denounce this obsession with motherhood that leads Nnu Ego to a sad and emotionally barren life. She had devoted her whole life to her children, a life of suffering and hardships in her herculean struggle for their survival, only to die alone, with no child to hold her hand and no friend to talk to her. She had never really made many friends, so busy had she been building up her joys as a mother.

\section{Afro-Brazilian mothers ${ }^{10}$}

An overview of the images constructed by patriarchal and colonial ideology about Afro-Brazilian women shows great emphasis on their bodies, as objects to be used and abused by men. In Brazilian canonical literature, the image of black women and of the mulatto woman was traditionally constructed as that of an eroticized, "infertile"11 woman, that is, they are never seen as mothers; on the contrary, they are always sexually available to satisfy man's sexual drives, adding to the arduous tasks of daily slave labour or in the kitchen, where they seem to enjoy their servitude, like Bertoleza. ${ }^{12}$

Beautiful and appetizing mulatto women such as Rita Baiana and Gabriela people Brazilian novels, thirsty for sex and eager to satisfy men's sexual urges; many other black female characters, sometimes envious spiteful of the beauty and youth they lack, are seen as "mules", destined to heavy work in the fields or in the slaveowner's kitchen. Most Brazilian children have sweet memories of several of Monteiro Lobato's children's books about the Sitio do Picapau Amarelo (The ranch of the yellow woodpecker), where we read as quite romantic the image of black cook "tia Nastácia", happy to prepare the delicious meals in the family's kitchen.

At the same time, the role of the black woman as mother was cruelly distorted, especially during the harsh reality of slavery, when black women slaves did not mother their offspring, but the white children of their oppressors, as "amas de leite" (milk nannies). The experience of motherhood for a woman slave was usually a painful and cruel experience; most often, their children had been the consequence of rape by white men. The black men did not always treat black 
women in a loving, affectionate manner; sometimes, black women were the only escape valve for the fury, powerlessness, frustrations and cruelty which the black men had to endure in the hands of their masters. At the same time, these black mothers had to cope with their constant anxiety of losing their children, so often having to move far away from their mothers, because they were frequently sold into slavery to other masters.

Contemporary social reality shows us that among Brazilian women of African descent, a majority of females are heads of household, forming and maintaining matrifocal families. In literature by AfroBrazilian women writers, images of mothers emerge that surprise and overcome all the stereotypes and transcend the physicality of this sometimes harsh reality.

In the novel Um Defeito de Cor (A Colour Defec-2006), by the Afro-Brazilian novelist Ana Maria Gonçalves, Kehinde-the narrator-protagonist of this 900-page epic of the Brazilian slave-is also raped; however, not as a powerless victim of male war rivalries as her mother had been, but as a victim of her slaveowner's lust. On the eve of her marriage to the slave Lourenço, the fourteen-year old Kehinde loses her virginity, and this most violent act takes place in the presence of her fiancée, who afterwards is also raped and castrated. As numberless black women slaves, she experiences the monstrous forces of slavery in her own body, adding to the cultural, psychological, spiritual, and economic marks of slavery. While still recovering from deep depression caused by such a traumatic experience, Kehinde realizes she's pregnant of the man she hates most. The birthing act is also shown in its physical details:

While crossing the sea, I united the waters of my entrails with those of Iemanjá [...] while I made incredible efforts and said my orikis, ${ }^{13}$ asking Nanã, the mother of everything that exists, to give me a child without defects, healthy and intelligent, with the star of good fortune. I prayed for him to be taken in Her arms, guiding the child safely out of my body. (Gonçalves 186, 189)

Other readings of Afro-Brazilian women writers' fictional narratives ${ }^{14}$ reinforce the image of black mothers as varied and complex, with different reactions and attitudes to cope with the cruel reality of their lives, not only as slave women, but also in contemporary society, where their condition has not improved much. See, for example, Conceição Evaristo's novel Becos da Memória, which presents us a mother who is forced to sell her daughter into prostitution, in order to save the whole family:

\begin{abstract}
The girl's mother dreams of milk, bread, money. She dreams of the medicine that her sick child needs, and a job for her drunk husband. She dreams of a better future for her daughter, less haunted by poverty. The mother dreams of a life without so much need. [...] One day, a man arrived to supply the bars of the favela with cigarettes. Unlike us, he speaks roughly and with the hands in his pockets. The girl's mother looks at the man's hand. They look at each other. She already knows the man's vice. $\mathrm{He}$ is also aware of her needs. He is quick, straightforward, cruel. "How much do you want, woman?" The girl's mother does not reply. The man gives her some money. The mother calls the girl. "Nazinha, follow the guy!" The man takes the girl by the hand and leaves. (Evaristo 33, minha tradução)
\end{abstract}

However, these women are far from being defeated by suffering, which they refuse to accept as their lot. Despite the violence perpetrated against their bodies and spirit, they find within themselves the strength to transcend this harsh reality. Kehinde rose from slavery into becoming a successful business woman in Africa; at the end of the novel, she embarks on a journey back to Brazil, in order to find her son, who had been sold into slavery by his Portuguese father-a journey that also implies her search for a deep understanding of her AfroBrazilian roots, her hybrid nature. In Ponciá Vicêncio (2003), a novel by the Afro-Brazilian writer Conceição Evaristo, the main character's several pregnancies never come to full term, as if she did not want to transmit to her children the legacy of suffering and consequent insanity in which she finds refuge. However, Ponciá does not produce babies, she creates art, through which she will preserve the memory of her black ancestry. In close association with myths of creation, the clay that 
she finds in the river is transformed into human images of her African heritage, which will serve as the basis for a better future for Afro-Brazilians.

In fiction, as well as in real life, several of these remarkable-though utterly invisible-women are head of families which they try to improve as best as they can. They also become religious and community leaders, thus expanding the range of their positive action. They gradually and increasingly overcome their traditional roles as "human mules" of slave labour, the selfless, sweet and devoted "amas de leite" of colonial times, the exotic mulatto women of man's erotic phantasies.

We will never fully grasp the complexity and extent of the experience of slavery, especially for the enslaved population. The consequences of the horrors these black women had to endure as mothers in a patriarchal, colonial, society that championed slavery for centuries are unmined sources that will be forever found in the "archives of the unwritten" (Chase-Riboud 96). In the foreword to his novel The President's Daughter, the AfroAmerican novelist Barbara Chase-Riboud comments:

A novel is a legitimate illumination of the ambiguities of historical reality. [...] We can only hope to find a grain of truth in the ocean of desert sand which is humanity's historical memorial. (Chase-Riboud 96)

That is, I believe, what these writers have been doing brilliantly. From sorrow to happiness, from disillusion to hope, from defeat to victory, from immanence to transcendence, each small step is taken daily by these invisible characters which people our history and fiction.

\section{Notes}

1. For Kristeva (1982), the "Real"-pre-symbolic, i.e., beyond representation-is the dangerous force of the (body) of the mother, from which the self develops/ transcends, into the Imaginary and the Symbolic, origin of culture and civilization.

2. For further studies about motherhood see STEVENS, Cristina (org). Maternidade e feminismo: Diálogos interdisciplinares. Editora Mulheres/EDUNISC, Florianópolis, 2007.
3. See Stevens, Cristina. "O corpo da mãe na literatura uma ausência presente" in Stevens, Cristina \& Swain, Tania. A construção dos corpos - perspectivas feministas. Florianópolis: Editora Mulheres, 85-116.

4. Jane Flax: "Postmodernism and Gender Studies in Feminist Theory", in Signs 12.4 (1987); Judith Butler: "Fundamentos contingentes: feminismo e a questão do pós modernismo" Trad. Pedro Maria Soares. In Cadernos Pagu 11 (1998): 11-42; Gayle Rubin: “The traffic in women; notes on the 'Political Economy' of sex", in Toward an anthropology of women. Monthly Review Press, New York, 1975.

5. s.muni.cz/el/1423/jaro2006/SOC402/um/1239861/ BUTLER. pdf (access in 28.05.2015).

6. The The President's Daughter fictionalizes the life of Harriet Hemings, daughter of the mixed-race slave Sally Hemings and Thomas Jefferson.

7. The novelist's name was Elaine Cynthia Potter Richardson; at 17, she left Antigua to become an au pair in New York, and changed her name to Jamaica Kincaid. She broke off all contact with her mother. (http://en.wikipedia.org/wiki/Jamaica_Kincaidacesso em 22.05.2015).

8. Unheimlich: the uncanny, homesickness. A notion of both familiarity and threat manifesting through the same person, object, or event. In the text "The Uncanny", Freud conceptualizes that the things we find the most terrifying appear that way because they once seemed familiar. According to the psychoanalyst Chris Weldon, Ferenczi develops the concept that life is determined by the tendency of wish to return to the womb, which, according to him, is evident in the sexual act, when men unites with the body of the woman (Weldon: 28).

9. http://www.thecore.nus.edu.sg/landow/post/nigeria/ emecheta/emechetaov.html. Acesso em 22.05.2015.

10. For a detailed study of black motherhood in Brazilian society, see Vania M.F.Vasconcelos. "No colo das Iabás: raça e gênero em escritoras afrobrasileiras contemporâneas" (PhD thesis. University of Brasília, 2014).

11. According to traditional race theories, the crossbreeding between different races would result in sterility in the second or third generations. This idea is also related to the origin of the word "mulatto", which comes from "mule" a hybrid offspring, created as a result of the cross-breeding between the mare and the ass, which resulted in these sterile animals. The words "mulatto/a" were adopted in a pejorative way to describe the children of the slaves and black women.

12. Bertoleza and Rita Baiana, female characters in $O$ Cortiço, by Aluisio de Azevedo (1890). Gabriela is 
another mulatto woman, in Jorge Amado's novel Gabriela (1958).

13. Yoruba: text. They believed that calling someone by his/her oriki will inspire them, since it will calm their ori (brain).

14. See also, the short stories and poems published in Cadernos Negros, Toda Mulher Sangra (Lia Vieira), e Leite de Peito (Geni Guimarães), "Vozes Femininas no Quilombo da Literatura: a interface de gênero e raça nos Cadernos Negros" MA Dissertation (Adelia R. S. Mathias, Universidade de Brasília, 2014), and Vania Vasconcelos PhD (mentioned before).

\section{References}

Agonito, Rosemary. History of Ideas on Woman. New York: Paragon, 1977.

Barad, Karen. "Post humanist performativity: towards an understanding of how matter comes to matter". Signs, A Journal of Women in Culture and Society. University of Chicago Press. 28.3 (2003): 801-831.

Beauvoir, S. The Second Sex. First edition (1949). Trans. H. M. Parshley. New York: Vintage Books, Random House, 1989.

Butler, Judith. "Fundamentos contingentes: feminismo e a questão do pós modernismo." Trad. Pedro Maria Soares. Cadernos Pagu 11 (1998): 11-42.

Gender Trouble: Feminism and the Subversion of Identity. New York: 1990.

Bodies That Matter: On the Discursive Limits of "Sex". New York: Vintage Books, 1993.

Chase-Riboud, Barbara. The President's Daughter. Chicago: Chicago Review Press, 2009. kindle edition.

Del Priore, M. Ao sul do corpo. Condição feminina, maternidades e mentalidades no Brasil colônia. Rio de Janeiro: Livraria José Olímpio Editora, 1993.

Emecheta, Buchi. The Joys of Motherhood. Second edition. Harlow: Heinemann, 2008.

Evaristo, Conceição. Becos da Memória. Belo Horizonte: Mazza Edições, 2006.

Ponciá Vicêncio. Belo Horizonte: Mazza Editore, 2003.

Foucault, Michel. History of Sexuality I. Trans. Robert Hurley. New York: Vintage, 1990.

Freud, Sigmund. “The Uncanny”. First edition English (1955). In Freud, Standard Edition VII. Trans. James Strachey. London: The Hogarth Press, 1971.

Gonçalves, Ana Maria. Um defeito de cor. Rio de Janeiro: Record, 2006.
Haraway, Donna. Cyborg Manifesto. New York: Routledge, 1991.

Hirsch, M. The Mother-Daughter Plot. Narrative, Psychoanalysis and Feminism. Bloomington: Indiana University Press, 1989.

Irigaray, L. Sexes and genealogies. Trans. Gillian C. Gill. New York: Columbia University Press, 1993.

Kincaid, Jamaica. The Autobiography of My Mother. Second edition. Harmondsworth: Penguin, 1997.

Kristeva. Julia. Powers of Horror: An Essay on Abjection. Trans. Leon S. Roudiez. New York: Columbia University Press, 1982.

Morrison, Toni. Beloved. New York: Plume Books, 1987.

O'reilly, Andrea. Toni Morrison and motherhood. A politics of the heart. 2nd ed. Albany: State of New York Press, 2004.

Tanner, Nancy. "Matrifocality in Indonesia and Africa and Among Black Americans" in Rosaldo, M. Z. \& Lamphere, Women, Culture and Society. L. Stanford University Press, 1974 (p. 129-156.

Weldon, E.V. Mother, Madonna, Whore-the Idealization and Denigration of Motherhood. London: Free Association Books, 1988.

Recebido em: 04/06/2015 Aceito em: 18/07/2015 
